\title{
Detecting the variability of Hydnum ovoideisporum (Agaricomycetes, Cantharellales) on the basis of Italian collections, and $\boldsymbol{H}$. magnorufescens sp. nov.
}

\author{
Vizzini $A^{1^{*}}$, Picillo $B^{2}$, Ercole $E^{1}$, Voyron $S^{1}$ and Contu $M^{3}$ \\ ${ }^{1}$ Dipartimento di Scienze della Vita e Biologia dei Sistemi, Università degli Studi di Torino, Viale P.A. Mattioli 25, \\ 10125 Torino, Italy \\ ${ }^{2}$ Via Roma 139, 81017 S. Angelo d'Alife (CE), Italy \\ ${ }^{3}$ Via Marmilla 12, 07026 Olbia, Italy
}

Vizzini A, Picillo B, Ercole E, Voyron S, Contu M 2013 - Detecting the variability of Hydnum ovoideisporum (Agaricomycetes, Cantharellales) on the basis of Italian collections, and $H$. magnorufescens sp. nov. Mycosphere 4(1), 32-44, Doi 10.5943 /mycosphere/4/1/2

Hydnum ovoideisporum is a species of the Hydnum rufescens complex recently described from Spain, and characterized by having a pileus with deep orange tones, ovoid to broadly ellipsoid basidiospores, and growing in Mediterranean areas on calcareous soil. In this paper, four South Italian collections found under Quercus and traditionally determined as H. rufescens, were analyzed on the basis of morphological and molecular (ITS) data; three of them were proven to be conspecific with $H$. ovoideisporum even though they differ from the type by globose to subglobose spores, and one has a smooth hymenophore. $H$. ovoideisporum $\mathrm{f}$. depauperatum $\mathrm{f}$. nov. is established for accommodating specimens with a smooth hymenophoral surface. Finally, $H$. magnorufescens sp. nov. is established for a collection with large basidiomes without strong orange-reddish tinges, and with globose to subglobose spores.

Key words - Biodiversity - cantharelloid clade - Hydnaceae - ITS nrDNA phylogeny - taxonomy

Article Information

Received 11 December 2012

Accepted 2 January 2013

Published online 28 January 2013

*Corresponding author: Alfredo Vizzini - e-mail - alfredo.vizzini@ unito.it

\section{Introduction}

The genus Hydnum L., typified by $H$. repandum L., traditionally encompasses fungi with pileate and stipitate, usually bright coloured basidiomata (whitish to yellow or orange-reddish) characterized by an aculeate hymenophore, with spines paler than pileus or concolorous, a fleshy, brittle, homogeneous, not zoned monomitic context, with inflating, thin-walled, branched, clamped hyphae, basidia cylindrical-clavate, (3-)4-5(-6)-spored, stichic (basidia with nuclear spindles arranged longitudinally) with basal clamp-connection, spores subglobose to obovoid-elliptical, smooth, colourless, and cystidia usually absent (Hall \& Stuntz 1971, as Dentinum Gray; Maas Geesteranus 1971, 1974, 1975, 1976, Harrison \& Grund 1987, Forte \& Pieri 1993, Otto 1997, Pegler et al. 1997, Arnolds 2003). They are terrestrial in deciduous and coniferous forests (Maas Geesteranus 1971, 1975), occasionally also on decayed wood, and ectomycorrhizal (Raidl \& Agerer 1992, Agerer et al. 1996, Kraigher \& Agerer 1996, Tedersoo et al. 2010). The genus was classified in Cantharellales Gäum. by Kreisel (1969) on the basis of its stichic basidia; this placement was corroborated by recent molecular analyses 
(Pine et al. 1999, Moncalvo et al. 2006, Matheny et al. 2007). In particular, Pine et al. (1999) placed it close to Craterellus Pers. and Cantharellus Adans. ex Fr., Moncalvo et al. (2006) and Matheny et al. (2007) in the cantharelloid clade as sister to Sistotrema Fr.

Within Hydnum, species identification relies primarily on the observation of a rather limited set of features, such as the basidioma habit, pileus color, presence of umbilicus in the pileus, spine shape and attachment to the stipe, a central or excentric stipe, number of sterigmata in the basidia, and spore shape (Maas Geesteranus 1971, 1975, Pegler et al. 1997, Arnolds 2003, Ostrow \& Beenken 2004). Five Hydnum species are traditionally recognized in Europe separated by their morphological differences, namely Hydnum albidum Peck, $H$. repandum L., $H$. rufescens Pers., $H$. umbilicatum Peck and $H$. ellipsosporum Ostrow \& Beenken (Hrouda 1999, Ostrow \& Beenken 2004, Huhtinen \& Ruotsalainen 2006, Grebenc et al. 2009). Within these taxa H. rufescens is characterized by having usually small and slender basidiomata with orange-reddish colours, a not umbilicate pileus, typically central stipe, free to adnate, not decurrent and not spathulate aculei, and globose to subglobose spores (Ostrow \& Beenken 2004, Huhtinen \& Ruotsalainen 2006, Grebenc et al. 2009). Agerer et al. (1996), using a PCR-RFLP approach, unveiled a high variability of the ITS region of $H$. rufescens specimens from different European areas. This high variability was later confirmed by the ITS phylogenetic analysis on European Hydnum species by Grebenc et al. (2009), which yielded six well supported monophyletic clades (named as RU1-RU6) for the specimens morphologically attributable to $H$. rufescens; in general, they were not able to assign specific distinguishing morphological features to any clade. Data from Agerer et al. (1996) and Grebenc et al. (2009) supported the idea of several new, yet undescribed phylogenetic species within the collections with the typical morphological features of $H$. rufescens (hereafter referred as the $H$. rufescens complex). Finally, Olariaga et al. (2012) recognized within the $H$. rufescens complex the same six clades, RU1-RU6 (all with globose to subglobose spores) and two additionally monophyletic clades consisting of collections with ovoid to broadly ellipsoid basidiospores, which they formally described as new species: Hydnum ovoideisporum Olariaga, Grebenc, Salcedo \& M.P. Martín, widespread in the Iberian-Mediterranean area, distinguished by the pileus with deep orange tones and strong preference for calcareous soils; Hydnum vesterholtii Olariaga, Grebenc, Salcedo \& M.P. Martín, from the Pyrenees, mainly characterized by a ochre to light ochre pileus.

The purpose of the present study was to determine, using both morphological and molecular characters (ITS region), whether Italian specimens collected under Quercus in Mediterranean areas and characterized by Hydnum rufescens-like basidiomes and globose to subglobose basidiospores represent new phyletic lines or are attributable to already described species or phylogenetic clades. Some of these collections are distinguished by having an entirely smooth hymenophore.

\section{Methods}

\section{Morphology}

Macromorphological features were described from fresh specimens. The micromorphological descriptions are based upon study of both fresh and herbarium material, the latter rehydrated in $5 \% \mathrm{KOH}$ and stained in ammoniacal Congo red or $1 \%$ Phloxin. Thirty-two spores were measured in $5 \% \mathrm{KOH}$ per collection. The number of collections measured is indicated by a "c". The width of each basidium was measured at the widest part, and the length was measured from the apex (sterigmata excluded) to the basal septum. The following abbreviations are used: $\mathrm{Q}=$ the quotient of length and width of the spores in side view; $\mathrm{Qm}=$ average quotient. Colour terms in capital letters (e.g. Mikado Orange, Plate III) are those of Ridgway (1912). Author citations follow the Index FungorumAuthors of Fungal Names (http://www.indexfungorum.org/authorsoffung alnames.htm). Herbarium abbreviations are according to Thiers (2012) except that BP refers to the personal herbarium of $\mathrm{B}$. Picillo. Diagnoses of the new taxa are deposited in MycoBank (http://www.mycobank.org/DefaultPage.aspx). 
DNA extraction, PCR amplification, and DNA sequencing

Genomic DNA was isolated from $1 \mathrm{mg}$ of four dried herbarium specimens (TO HG2815-TO HG2818), by using the DNeasy Plant Mini Kit (Qiagen, Milan Italy) according to the manufacturer's instructions. Universal primers ITS1F/ITS4 were used for the ITS region amplification (White et al. 1990, Gardes $\&$ Bruns 1993). Amplification reactions were performed in a PE9700 thermal cycler (PerkinElmer, Applied Biosystems) following Vizzini et al. (2011). The PCR products were purified with the AMPure XP kit (Beckman) and sequenced by MACROGEN Inc. (Seoul, Republic of Korea). Sequences were checked and assembled using Geneious v5.3 (Drummond et al. 2010), submitted to GenBank

(http://www.ncbi.nlm.nih.gov/genbank/) and their accession numbers are reported in Table 1 and Fig. 1.

\section{Sequence alignment and phylogenetic analysis}

Sequences obtained in this study were compared to those available in the GenBank database by using the blastn algorithm. Based on the blastn results, sequences were selected according to the outcomes of recent phylogenetic studies on Hydnum (Ostrow \& Beenken 2004, Grebenc et al. 2009, Olariaga et al. 2012). Alignments were generated using MAFFT (Katoh et al. 2002) with default conditions for gap openings and gap extension penalties. The alignment was then imported into MEGA 5.0 (Tamura et al. 2011) for manual adjustment. The best-fit models were estimated by both the Akaike Information Criterion (AIC) and the Bayesian Information Criterion (BIC) using jModelTest 0.1.1 (Posada 2008) to provide a substitution model for the alignment. The $\mathrm{GTR}+\mathrm{G}$ substitution model was chosen for the analyses. Phylogenetic analyses were performed using the Bayesian Inference (BI) and the Maximum likelihood (ML) approaches. Sistotrema alboluteum (AJ606042) and S. muscicola (AJ606040) were used as outgroup taxa in both analyses. BI of phylogeny using Monte Carlo Markov Chains (MCMC) was carried out with MrBayes 3.1.2 (Huelsenbeck \& Ronquist 2001). Four incrementally heated simultaneous
MCMC were run over 10 million generations. Trees were sampled every 1,000 generations resulting in an overall sampling of 10,001 trees. The first 2,500 trees were discarded as "burn-in" $(25 \%)$. The "burn-in" value was evaluated using Tracer 1.5 (Rambaut \& Drummond 2007). For the remaining trees, a majority rule consensus tree showing all compatible partitions was computed to obtain estimates for Bayesian Posterior Probabilities (BPP). Branch lengths were estimated as mean values over the sampled trees. ML estimation was performed through RAxML v.7.0.4 (Stamatakis 2006) with 1,000 bootstrap replicates (Felsenstein 1985) using the GTRGAMMA algorithm to perform a tree inference and search for a good topology. Support values from bootstrapping runs (MLB) were mapped on the globally best tree using the "-f a" option of RAxML and "-x 12345" as a random seed to invoke the novel rapid bootstrapping algorithm. BI and ML analyses were run on the CIPRES Science Gateway web server (Miller et al. 2010). Only BPP values over 0.70 and MLB over $50 \%$ are reported in the resulting tree (Fig. 1). Pairwise \% identity values of ITS sequences were calculated using MEGA 5.0 (Tamura et al. 2011).

\section{Results}

\section{Phylogenetic analyses}

Both Bayesian and Maximum likelihood analyses produced the same topology; therefore, only the Bayesian tree with both BPP and MLB values is shown (Fig. 1). The ITS dataset comprised 87 taxa (including 76 from GenBank and 7 from UNITE, http://unite.ut.ee/) and 682 characters, and contains 281 variable sites. Of these, 200 are parsimony-informative.

All the phylogenetic European species recognized by Olariaga et al. (2012) are also recovered in our nrITS sequence analyses (Fig. 1). Fourteen main clades were obtained and phylogenetic relationships between them were in accordance with the results obtained in the previously cited work. Accordingly, these clades were named as in Olariaga et al. (2012). Our newly sequenced collections clustered in two distinct clades. Three of them in the well supported Hydnum ovoideisporum clade (1 BPP, 100 MLB), and one in the also well 


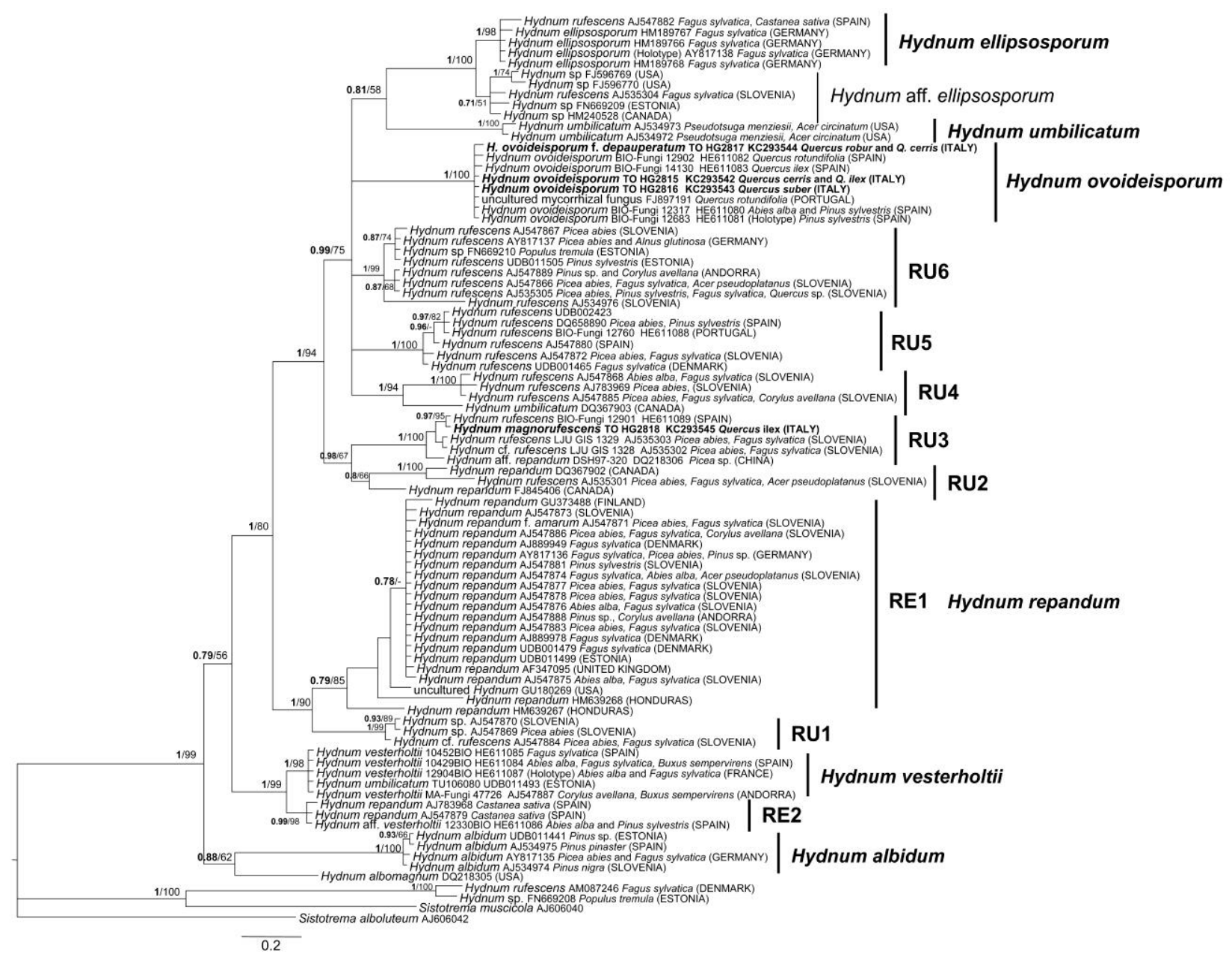

Fig. 1 - Bayesian phylogram obtained from the general nrITS sequence alignment. Sistotrema alboluteum and S. muscicola were used as outgroup taxa. Support values in either the Bayesian (Posterior Probabilities values [BPP]) or maximum likelihood (ML Bootstrap percentage [MLB]) analyses are indicated. Only BPP values over 0.70 (in bold) and MLB values over $50 \%$ are given above clade branches. Newly sequenced collections are in bold. For each collection, GenBank or UNITE accession number, and when possible, putative host tree and geographical distribution (country) are reported. Clades were named as in Olariaga et al. (2012). In the H. ovoideisporum, RU3 and $H$. vesterholtii clades, collections are also provided with herbarium number. - Bar $=$ substitutions per site.

supported clade RU3 (Hydnum magnorufescens) (1 BPP, 100 MLB). Pairwise $\%$ identity values of sequences belonging to the two clades are of 99.7 and 99.6, respectively, and corroborating the robustness of clades themselves.

\section{Taxonomy}

Hydnum ovoideisporum Olariaga, Grebenc, Salcedo \& M.P. Martín, Mycologia 104(6): 1446 (2012)

MycoBank 563524
Description based on Italian collections.

Basidiomata pileate and stipitate; development gymnocarpic and stipitocarpic or pileostipitocarpic (sensu Reijnders 1963).

Pileus 8-40 mm diam., convex to plane or slightly depressed in the centre; margin only slightly involute, soon straight, entire, finally slightly lobed or sinuous-undulate; surface dry, at first tomentose, felty, pruinose towards the margin, then glabrescent, rarely with small and erect scales at margin and centre, sometimes zoned (as Lactarius porninsis Rolland), orange-brown to bright reddish-orange (Light 

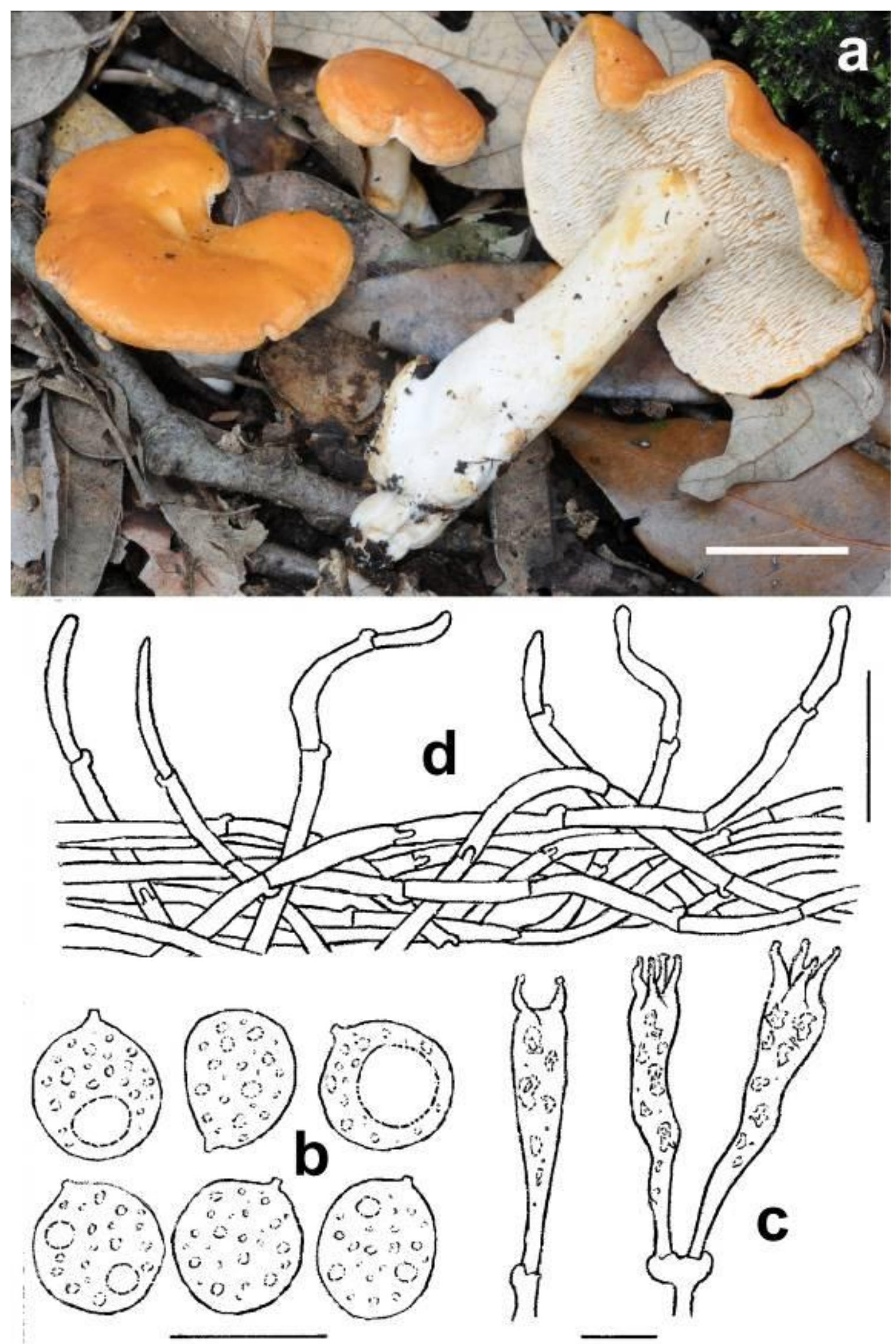

Fig. 2 - Hydnum ovoideisporum. Macroscopic and microscopic features (from TO HG2815). a Basidiomata in situ. b Spores. c Basidia. d Pileipellis. - Bars: $\mathbf{a}=10 \mathrm{~mm} ; \mathbf{b}, \mathbf{c}=10 \mu \mathrm{m} ; \mathbf{d}=20 \mu \mathrm{m}$. Photo and line drawings by B. Picillo. 
Salmon-Orange, Plate II; Mikado Orange, Plate III; Rufous, Apricot Orange, Plate XIV); margin white. Hymenophore spinose, adnate, not decurrent; spines conical, acute, not flattened-spathulate, not fimbriate, crowded, up to $4 \mathrm{~mm}$ long, at first white, then pale ochreorange (Capucine Buff, Plate III; Salmon-Buff, Plate XIV). Stipe $15-70 \times 4-12 \mathrm{~mm}$ central to excentric, slender, cylindrical or clavate, the base often with white rhizomorphs; surface tomentose-pruinose, white or whitish, yellowing on handling (Orange-Buff, Capucine Yellow, Cadmium Yellow, Plate III). Context fleshy, firm but brittle in the pileus, more fibrous in the stipe, whitish, ochre-pinkish under the pileus and stipe surface, yellowing at the cut (Orange-Buff, Capucine Yellow, Cadmium Yellow, Plate III); smell weak, fungic, and taste hazel-nut like, sometimes slightly spicy-piquant after a long chewing. Spore print whitish, pale cream.

Hyphal system monomitic. Spores $(6.5-) 7.0-8.5(-9) \times(6.0-) 6.5-7.5(-8.0) \mu \mathrm{m},(\mathrm{c}$ $=2)$, on average $7.37 \times 6.87, \mathrm{Q}=(1.0-) 1.06-$ $1.18(-1.2), \mathrm{Qm}=1.07$, globose to (mostly) very slightly subglobose, smooth, thin-walled, hyaline, inamyloid, non-dextrinoid, with granular content, sometimes with one or more oil-drops, with a small cubic apiculus. Basidia $32-45 \times 7.5-8.5 \mu \mathrm{m}$, strictly clavate, clamped, usually four-spored, more rarely 2-3-5 spored, sterigmata 4-6.2 $\mu \mathrm{m}$ long, with granular content. Hymenial cistidia absent. Pileipellis consisting of a cutis of tightly interwoven

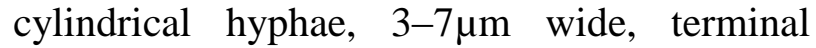
elements up to 60-70 $\times 3-3.5 \mu \mathrm{m}$, hyaline, repent (transition to a trichoderm), with rounded to slightly tapering apex, the other elements with orange-brown cytoplasmatic pigment. Subpellis not well differentiated. Hymenophoral trama consisting of parallel 3-6 $\mu \mathrm{m}$ wide hyphae. Stipitipellis made up of a cutis of subparallel, cylindrical hyphae, 1.5-4 $\mu \mathrm{m}$ wide, with some free terminal elements bearing a blunt apex, 3-4 $\mu \mathrm{m}$ wide, with an orange-brown cytoplasmatic pigment. Clampconnections present in all tissues.

Habitat and known distribution gregarious in Mediterranean Quercus woods, usually on calcareous soil. Fruiting in winter. So far known from Iberian Peninsula and Italy.
Material examined - Italy, Campania, prov. Caserta, Raviscanina, loc. Cerreto, $170 \mathrm{~m}$ a.s.1., Quercus cerris and Q. ilex, on calcareous soil, 05 Dec. 2010, leg. B. Picillo (TO HG2815, duplo in BP10/304); Italy, Sardinia prov. Olbia-Tempio P., Calangianus, loc. Le Grazie, on humus in a small wood of cork-oaks (Quercus suber), 18 Dec. 2011, leg. M. Contu (TO HG2816).

\section{Hydnum ovoideisporum f. depauperatum} Picillo, Vizzini \& Contu, f. nov. Fig. 3 MycoBank MB 802976

Etymology - the epithet, derived from the Latin adjective depauperatus, depauperata, depauperatum (impoverished, lacking of), refers to the hymenophore without spines.

It differs from the type in having a completely smooth hymenophore (nearly concolorous with the pileus) and globose to subglobose spores [(7-)7.5-8.5(-9) $\times(6.5-) 7-$ 8.2(-8.5) $\mu \mathrm{m}, \mathrm{Qm}=1.06]$. HG2817.

Holotype (here designated) - TO

Habitat and known distribution gregarious, among mosses, in Mediterranean Quercus woods, on argillose, basic soils. Fruiting in late autumn-winter. Very rare and know only from a single site in southern Italy.

Material examined - Italy, Campania, prov. Caserta, Raviscanina, loc. Farnieto, 225 a.s.l., between mosses, in a mixed Quercus robur and $Q$. cerris wood, with underwood composed mainly by Erica arborea and Ruscus aculeatus, on argillose-calcareous soil, 23 Dec. 2008 leg. B. Picillo (BP8/41); 27 Nov. 2011, leg. B. Picillo (TO HG2817, holotype); 29 Nov. 2011, leg. B. Picillo (BP11/461); 16 Dec. 2011, leg. B. Picillo (BP11/462); 20 Oct. 2012, leg. B. Picillo (BP 12/135); 04 Nov. 2012, legit B. Picillo (BP 12/162); 08 Dec. 2012, leg. B. Picillo (BP 12/210).

Hydnum magnorufescens Vizzini, Picillo \& Contu, sp. nov.

MycoBank MB 802977

Fig. 4 basidiomata.

It is characterized by large basidiomes (pileus up to $70 \mathrm{~mm}$ broad) with a pileus cream-ochre (with pinkish hues) without bright 


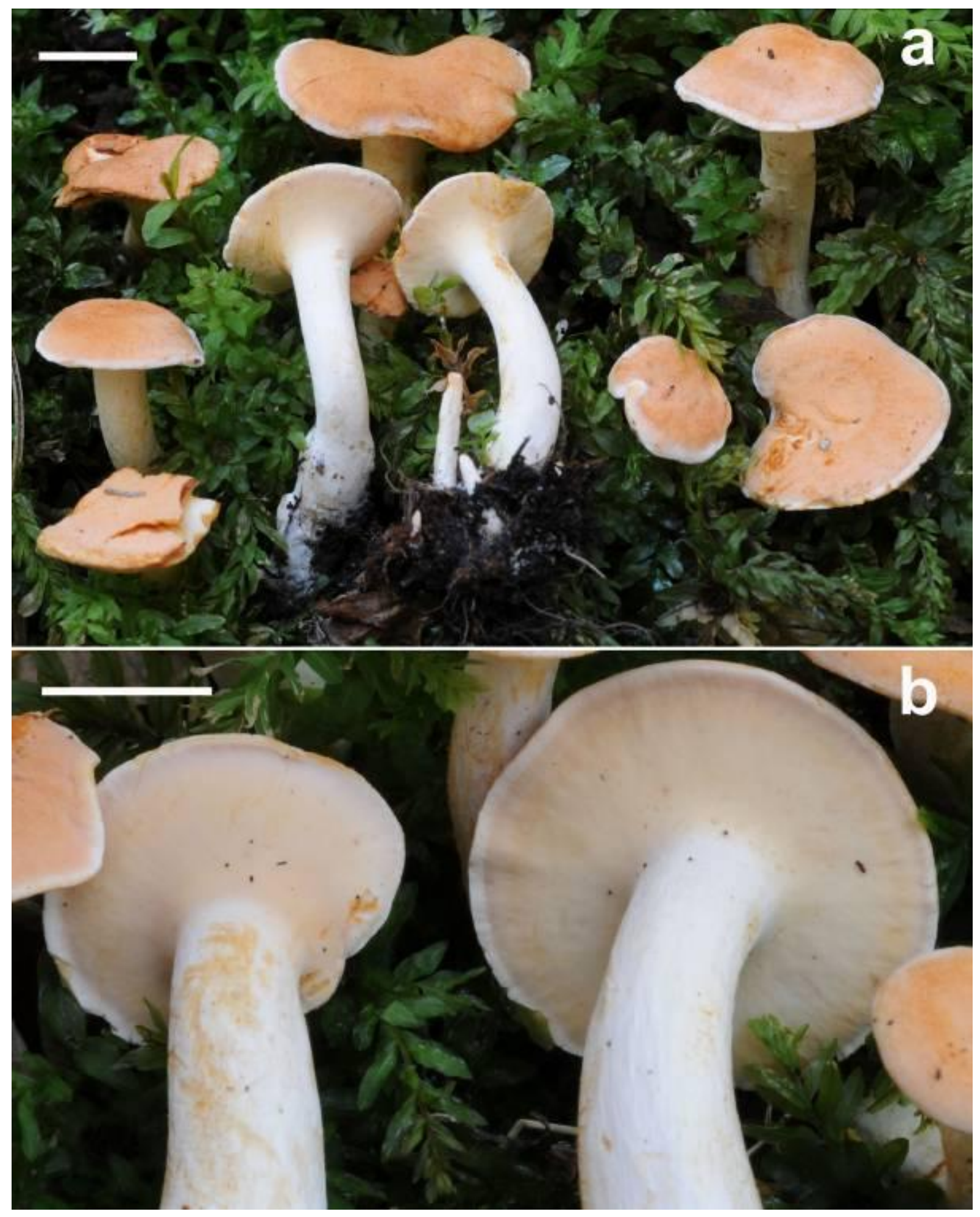

Fig. 3 - Hydnum ovoideisporum f. depauperatum. Macroscopic features. a Basidiomata in situ (TO HG 2817, holotype). b Hymenophore (BP11/461). - Bars: $\mathbf{a}, \mathbf{b}=10 \mathrm{~mm}$. Photos by B. Picillo.

orange-reddish tinges, not decurrent spines, globose to subglobose spores, $(6.8-) 7-8.5(-9)$ $\times(6.5-) 6.8-8.0(-8.5), \mathrm{Qm}=1.06$, and by a unique ITS sequence. HG2818.
Basidiomata pileate and stipitate; development gymnocarpic and stipitocarpic or pileostipitocarpic (sensu Reijnders 1963).

Pileus 30-55(70) $\mathrm{mm}$ diam., at first convex, pulvinate then applanate, not umbilicate-depressed, often irregular, gibbous 
and irregularly undulating; margin thick, persistently involute, only belatedly straight, at first entire, finally lobed or sinuous-undulate, splitting, sometimes slightly fimbriate and excedent; surface dry, velvety to felty, sometimes scaly in age, not zoned, creamochre with pinkish hues (Orange-Pink, Plate II; Capucine Buff, Plate III; Pale Salmon Color, Seashell Pink, Salmon-Buff, Plate XIV; Pale Ochraceous-Salmon, Plate XV; Pinkish Buff, Plate XXIX), yellowish-orange when handled (Light Salmon-Orange, Bittersweet Pink, Salmon-Orange, Plate II; Mikado Orange, Cadmium Orange, Plate III; Apricot Orange, Plate XIV), with a concolorous margin. Hymenophore spinose, adnate, not decurrent; spines subulate, conical, not flattened, not spathulate, acute, not fimbriate, sometimes joined at the base, soft-brittle, fragile, very crowded, uneven in length, up to $5 \mathrm{~mm}$ long, at first whitish, then with light cream-ochre shades (Pale Salmon Color, Seashell Pink, Plate XIV). Stipe $25-50 \times 8-17 \mathrm{~mm}$, usually central, rarely slightly excentric, short, stocky, about the same as the pileus diameter or slightly longer, solid, cylindrical or sometimes tapering or swollen below, with whitish rhizomorphs; surface minutely pruinosetomentose, glabrescent, paler than pileus, whitish-pale cream, discolouring ochre-Apricot orange (Apricot Buff, Apricot Orange, Plate XIV) on bruising. Context thick, firm, fragile and soft-fleshy, pale beige-cream, discolouring orange on exposure; smell faint, fruity, pleasant, and taste mild, slightly bitter in aged basidiomes. Spore print whitish-pale cream.

Hyphal system monomitic. Spores $(6.8-$ )7-8.5(-9) $\times(6.5-) 6.8-8.0(-8.5) \mu \mathrm{m},(\mathrm{c}=1)$, on average $=7.93 \times 7.48 \mu \mathrm{m}, \mathrm{Q}=(1.0-) 1.04-$ 1.14(-1.2), $\mathrm{Qm}=1.06$, globose to subglobose, smooth, thin-walled, hyaline, inamyloid, nondextrinoid, mostly1-guttate or multiguttate, with a small cubic apiculus. Basidia 38-46 $\times$ 7.5-9.5 $\mu \mathrm{m}$ strictly clavate, clamped, mainly four-spored, rarely 2-3-5 spored, sterigmata up to 5-7.8 $\mu \mathrm{m}$ long, with granular content. Hymenial cistidia absent. Pileipellis a disrupted and indefinite trichodermium (a cutis-trichodermium) consisting of cylindrical, interwoven, thin-walled hyphae, 3.5-8 $\mu \mathrm{m}$ wide; terminal hyphae as scattered and repent elements 3.5-8 $\mu \mathrm{m}$ wide, up to $180 \mu \mathrm{m}$ long, pluriseptate, usually with a rounded apex; cytoplasmatic pigment yellowish-ochre. Subpellis not well-developed. Hymenophoral trama consisting of parallel 3-5.5 $\mu \mathrm{m}$ wide hyphae. Stipitipellis made up of a cutis of subparallel, cylindrical hyphae, up to $10 \mu \mathrm{m}$ wide, with some free terminal elements bearing a blunt apex, 3-5 $\mu \mathrm{m}$ wide, with a yellowish cytoplasmatic pigment. Clamp-connections present in all tissues.

Habitat and known distribution gregarious in Mediterranean Quercus woods, on calcareous soil. Fruiting in winter. So far known only from Southern Italy.

Material examined - Italy, Campania, prov. Caserta, Baia e Latina, loc. Vallelunga, $320 \mathrm{~m}$ a.s.1., in a Quercus ilex wood, mixed with $Q$. cerris, $Q$. pubescens, Ostrya carpinifolia and Juniperus communis, on calcareous soil, 21 Dec. 2008, leg. B. Picillo (TO HG2818, holotype).

\section{Discussion}

Our four newly sequenced collections fell in two distinct clades: three in the $H$. ovoideisporum clade and one in the RU3 clade.

$H$. ovoideisporum is described with a unique combination of features such as slender basidiomata of the $H$. rufescens type with deep orange tinges in pileus, ovoid to broadly ellipsoid spores $[(7.5-) 8-10(-10.5) \times 6-7.5$ $\mu \mathrm{m} ; \quad \mathrm{Qm}=1.27-1.38], \quad$ a growth in Mediterranean areas (Iberian Peninsula) on calcareous soil, associated mainly with Quercus spp. (Olariaga et al. 2012). Our two collections (TO HG2815, TO HG2816), informally named as "Hydnum rufomediterraneum ad interim" in past local mycological shows, are clearly conspecific to $H$. ovoideisporum, as shown by the ITS analysis (Fig. 1). Morphologically they fit well the original description in Olariaga et al. (2012), but differ in having slightly smaller spores, globose to subglobose in shape (Fig. 2). A third globose-spored collection (TO HG2817) characterized by an entirely smooth but fertile hymenophore is also part of this clade (Fig. 3). 

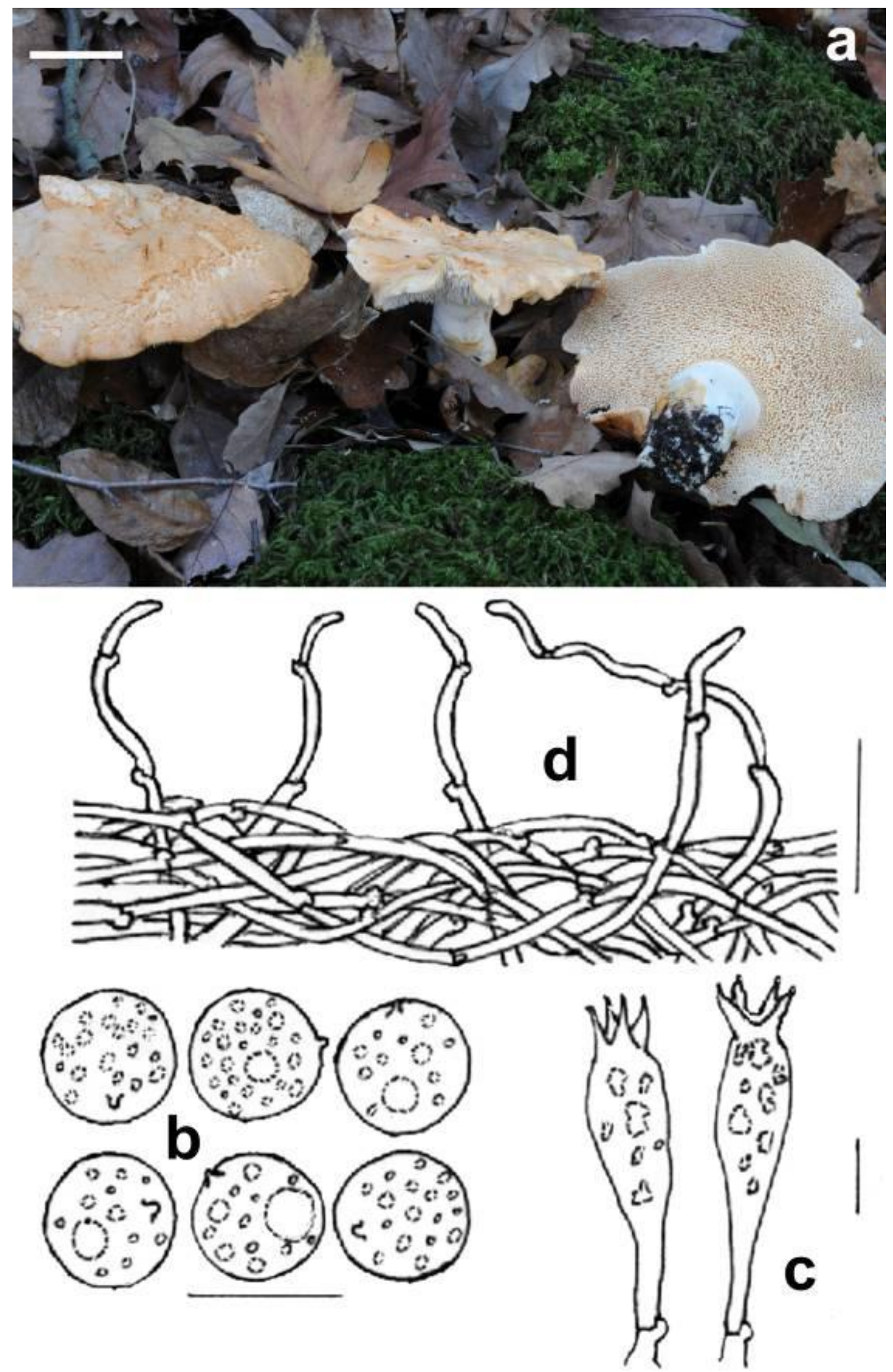

Fig. 4 - Hydnum magnorufescens. Macroscopic and microscopic features (from TO HG2818, holotype). a Basidiomata in situ. b Spores. c Basidia. d Pileipellis. - Bars: $\mathbf{a}=10 \mathrm{~mm} ; \mathbf{b}, \mathbf{c}=10$ $\mu \mathrm{m} ; \mathbf{d}=20 \mu \mathrm{m}$. Photo and line drawings by B. Picillo. 
Table 1 Newly sequenced Hydnum collections.

\begin{tabular}{lll}
\hline Collections & Coll. ID., Country, Date and Collector & ITS Acc. numbers \\
\hline Hydnum ovoideisporum & & \\
Hydnum ovoideisporum & TO HG2815, Italy, 05.12.2010, B. Picillo & KC293542 \\
Hydnum ovoideisporum f. depauperatum (holotype) & TO HG2816, Italy, 18.12.2011, M. Contu & KC293543 \\
Hydnum magnorufescens (holotype) & TO HG2817, Italy, 27.11.2011, B. Picillo & KC293544 \\
\hline
\end{tabular}

This anomalous hymenophore seems not be caused by a mycoparasitic attack (no alien mycelia or fructifications are present in the tissue, and basidia and spores are normally produced) but rather to a mutation in one or more genes controlling or driving the normal hymenophoral development. This is a probably steady mutation since other collections without spines were sampled in the same site for several consecutive years. This taxon is described in the present study as a new form (see above, f. depauperatum) of $H$. ovoideisporum. Also a sequence from north eastern Portugal derived from serpentine soil samples and ectomycorhizal tips in oak $(Q$. rotundifolia) forests (Branco \& Ree 2010) belongs to the same clade.

According to Grebenc et al. (2009) and Olariaga et al. (2012), the fact that the Qm values are constant and discriminating in well supported phylogenetic species such as $H$. albidum, $H$. ellipsosporum and $H$. repandum, indicates $\mathrm{Qm}$ as a reliable taxonomically informative character; in addition, the Qm seems very useful also for delimiting the recently established new species $H$. ovoideisporum and $H$. vesterholtii, although the sample size in both species is still poor. In our opinion, Grebenc et al. (2009) and Olariaga et al. (2012) may have overstressed the importance of spore shape and sporal Qm as a good marker in defining species within Hydnum. Collections with different spore shape may belong to the same species (e.g. $H$. ovoideisporum) and conversely collections with similar Qm may be attributable to different phylogenetic species (clades RU1RU6; Fig. 1; Grebenc et al. 2009, Olariaga et al. 2012).

In both Bayesian and ML analyses, Hydnum magnorufescens (TO HG2818) clustered in the clade RU3 with four collections (two from Slovenia, LJU GIS 1328 and LJU GIS 1329, one from Spain, BIO-Fungi
12901, and one from China, DSH97-320, the latter as Hydnum aff. repandum) (Fig. 1). All the sequences of this clade show a high ITS sequence homology (pairwise \% identity value =99.6). These collections are characterized, as Hydnum magnorufescens, by large basidiomata without orange tinges (Grebenc et al. 2009, Olariaga et al. 2012, http://hengduan.huh.harvard.edu/fieldnotes/spe cimens/search/search.zpt?st=hydnum\&action=s earch\&submit_button=Search). Future phylogenetic and morphological analyses including additional molecular markers for increased resolution could provide additional evidence for considering these collections conspecific to $H$. magnorufescens; at the moment data are still insufficient to draw this conclusion.

As regards the remaining clades of the $H$. rufescens complex (RU1-RU2 and RU4RU6), in accordance with Grebenc et al. (2009) and Olariaga et al. (2012), no morphological, ecological or geographical distinctive features can be specifically assigned to each clade (cryptic species); for example, collections belonging to the same clade do not share the ectomycorrhizal host tree or the geographical origin (Fig. 1). Under these circumstances, there is urgent need of typifying $H$. rufescens. The description of $H$. rufescens by Persoon (1799) does not provide data on microscopic characters, and no type specimen is conserved: "pileo carnoso subtomentoso e rufescente subcarneo, subulis acutis subcompressis incarnate-ochraceis, stipite tenuiusculo subcylindrico. Hab. passim in faginetis" (p. 95). Therefore, in our opinion, a recent collection from Netherlands under Fagus (or at least from northern Europe), after being sequenced, should be selected as a lectotype.

Finally, a sequence (UDB011493) from an Estonian collection identified as $H$. umbilicatum (TU106080) clustered within the $H$. vesterholtii clade (Fig. 1). Therefore, 
according to our analysis, $H$. vesterholtii, previously reported only from France, Spain and Andorra (Olariaga et al. 2012), could be present also in Estonia.

\section{Acknowledgements}

Caroline Hobart (Sheffield, U.K.) is thanked for improving the English text. Thanks to David Hibbett (Biology Department, Clark University, Worcester MA, USA) for providing useful data on the herbarium collection DSH97-320.

\section{References}

Agerer R, Kraigher H, Javornik B. 1996 Identification of ectomycorrhizae of Hydnum rufescens on Norway spruce and the variability if the ITS region of $H$. rufescens and $H$. repandum (Basidiomycetes). Nova Hedwigia 63(12), 183-194.

Arnolds E. 2003 - De stekelzwammen en Pruikzwammen van Nederland en België. Coolia 46 (3) supplement, 1-96.

Branco S, Ree RH. 2010 - Serpentine soils do not limit mycorrhizal fungal diversity. PLoS ONE 5(7): e11757. doi:10.1371/journal.pone.0011757

Drummond AJ, Ashton B, Buxton S, Cheung M, Cooper A, Duran C, Field M, Heled J, Kearse M, Markowitz S, Moir R, StonesHavas S, Sturrock S, Thierer T, Wilson A. $2010-$ Geneious v5.3. http://www.geneious.com/

Felsenstein J. 1985 - Confidence limits on phylogenies: an approach using the bootstrap. Evolution 39, 783-791.

Forte J, Pieri M. 1993 - Le genre Hydnum L.: Fr. Les espèces signalées dans le sud-est de la France. Bulletin de la Fédération des Associations Mycologiques Méditerranéennes1(3), 36-44.

Gardes M, Bruns TD. 1993 - ITS primers with enhanced specificity for basidiomycetesapplication to the identification of mycorrhizae and rusts. Molecular Ecology 2, 113-118.

Grebenc T, Martín MP, Kraigher H. 2009 Ribosomal ITS diversity among the European species of the genus Hydnum
(Hydnaceae). Anales del Jardín Botánico de Madrid 66S1, 121-132.

Hall D, Stuntz DE. 1971 - Pileate Hydnaceae of the Puget Sound area. I. White-spored genera: Auriscalpum, Hericium, Dentinum and Phellodon. Mycologia 63(6), 1099-1128.

Harrison KA, Grund DW. 1987 - Preliminary keys to the terrestrial stipitate hydnums of North America. Mycotaxon 28(2), 419-426.

Hrouda P. 1999 - Hydnaceous fungi of the Czech Republic and Slovakia. Czech Mycology 51(2-3), 99-155. (http://www.sci.muni.cz/botany/mycolog y/hydna.htm)

Huelsenbeck JP, Ronquist F. 2001 - MrBayes: Bayesian inference of phylogeny. Bioinformatics 17, 754-755.

Huhtinen S, Ruotsalainen J. 2006 - Variability of Hydnum rufescens in Finland: three taxa hidden under one name - and one appearance? Karstenia 46, 17-24.

Katoh K, Misawa K, Kuma K, Miyata T. 2002 - MAFFT: a novel method for rapid multiple sequence alignment based on fast Fourier transform. Nucleic Acids Research 30, 3059-3066.

Kraigher H, Agerer R. 1996 - Hydnum rufescenc. In: Colour Atlas of Ectomycorrhizae (ed. Agerer R). Einhorn-Verlag, Schwäbisch Gmünd, plate 92.

Kreisel H. 1969 - Grundzüge eines natürlichen Systems der Pilze. Gustav Fischer Verlag/Cramer, Jena, Germany.

Maas Geesteranus RA. 1971 - Hydnaceous fungi of the Eastern Old World. Verhandelingen der Koninklijke Nederlandse Akademie van Wetenschappen, afd. Natuurkunde, Tweede reeks 60(3), 1-176.

Maas Geesteranus RA. 1974 - Hydnaceous fungi of the eastern Old World. Supplement. Proceedings van de Koninklijke Nederlandse Akademie van Wetenschappen Section C. 77, 477-495.

Maas Geesteranus RA. 1975 - Die terrestrischen Stachelpilze Europas (The terrestrial hydnums in Europe). Verhandelingen der Koninklijke Nederlandse Akademie van 
Wetenschappen, afd. Natuurkunde, Tweede reeks 65, 1-127.

Maas Geesteranus RA. 1976 - Notes on Hydnums X. Proceedings van de Koninklijke Nederlandse Akademie van Wetenschappen Section C. 79, 273-289.

Matheny PB, Wang Z, Binder M, Curtis JM, Lim YW, Nilsson HR, Hughes KW, Hofstetter V, Ammirati JF, Schoch C, Langer E, Langer G, McLaughlin DJ, Wilson AW, Frøslev TG, Ge ZW, Yang ZL, Baroni TJ, Fischer M, Hosaka K, Matsuura K, Seidl MT, Vauras J, Hibbett DS. 2007 - Contributions of $\mathrm{rpb} 2$ and tef1 to the phylogeny of mushrooms and allies (Basidiomycota, Fungi). Molecular Phylogenetics and Evolution 43, 430451.

Miller MA, Pfeiffer W, Schwartz T. 2010 Creating the CIPRES Science Gateway for inference of large phylogenetic trees. In: Proceedings of the Gateway Computing Environments Workshop (GCE), 14 Nov. 2010, New Orleans, LA pp 1-8.

Moncalvo J-M, Nilsson RH, Koster B, Dunham SM, Bernauer T, Matheny PB, Porter TM, Margaritescu S, Weiß M, Garnica S, Danell E, Langer G, Langer E, Larsson E, Larsson K-H, Vilgalys R. 2006 - The cantharelloid clade: dealing with incongruent gene trees and phylogenetic reconstruction methods. Mycologia 98(6), 937-948.

Olariaga I, Grebenc T, Salcedo I, Martín MP. 2012 - Two new species of Hydnum with ovoid basidiospores: H. ovoideisporum and $H$. vesterholtii. Mycologia 104(6), 1443-1455.

Ostrow H, Beenken L. 2004 - Hydnum ellipsosporum spec. nov.

(Basidiomycetes, Cantharellales) - ein Doppelgänger von Hydnum rufescens Fr. Zeitschrift für Mykologie 70(2), 137156.

Otto P. $1997 \quad-\quad$ Kommentierter Bestimmungsschlüssel der terrestrischen Stachelpilze Deutschlands mit taxonomischen und nomenklatorischen Anmerkungen. Boletus 21, 1-21.

Pegler DN, Roberts PJ, Spooner BM. 1997 -
British Chanterelles and Tooth Fungi. Royal Botanical Gardens, Kew, London.

Persoon DCH. 1799 - Observationes mycologicae. Pars Secunda. Lipsiae et Lucernae.

Pine EM, Hibbett DS, Donoghue MJ. 1999 Phylogenetic relationships of cantharelloid and clavarioid Homobasidiomycetes based on mitochondrial and nuclear rDNA sequences. Mycologia 91, 944-963.

Posada D. 2008 - jModeltest: phylogenetic model averaging. Molecular Biology and Evolution 25, 1253-1256.

Raidl S, Agerer R. 1992 - Studien an Ektomykorrhizen XLII. Ontogenie der Rhizomorphen von Laccaria amethystina, Hydnum rufescens und Sarcodon imbricatum. Nova Hedwigia 55(3-4), 297-307.

Rambaut A, Drummond AJ. 2007 - Tracer v1.4. Available from http://beast.bio.ed.ac.uk/Tracer

Reijnders AFM. 1963 - Les problèmes du développement des carpophores des Agaricales et de quelques groupes voisins. W. Junk, den Haag, The Netherlands.

Ridgway R. 1912 - Color standards and color nomenclature. Washington, D.C., published privately (by the author).

Stamatakis A. 2006 - RAxML-VI-HPC: Maximum likelihood-based phylogenetic analyses with thousands of taxa and mixed models. Bioinformatics 22, 26882690.

Tamura K, Peterson D, Peterson N, Stecher G, Nei M, Kumar S. 2011 - MEGA5: Molecular Evolutionary Genetics Analysis using Maximum Likelihood, Evolutionary Distance, and Maximum Parsimony Methods. Molecular Biology and Evolution 28, 2731-2739.

Tedersoo L, May TW, Smith ME. 2010 Ectomycorrhizal lifestyle in fungi: global diversity, distribution, and evolution of phylogenetic lineages. Mycorrhiza 20, 217-263.

Thiers B. 2012 (continuously updated) - Index Herbariorum: A global directory of public herbaria and associated staff. New 
York Botanical Garden's Virtual Herbarium. sweetgum.nybg.org/ih/.

Vizzini A, Contu M, Musumeci E, Ercole E. 2011 - A new taxon in the Infundibulicybe gibba complex (Basidiomycota, Agaricales, Tricholomataceae) from Sardinia (Italy). Mycologia 103, 203-208.
White TJ, Bruns T, Lee S, Taylor J. 1990 Amplification and direct sequencing of fungal ribosomal RNA genes for phylogenetics. In: PCR Protocols (eds MA Innis, DH Gelfand, JJ Snisky, TJ White). Academic Press, London, pp. 315-322. 